$\begin{array}{llllllllll}\text { M } & \bar{A} & \text { T } & \text { E } & \text { R } & \text { I } & \bar{A} & \text { L } & \text { S }\end{array}$

Marek Kazimierz Kamiński

Tadeusz Manteuffel Institute of History at Polish Academy of Sciences

\title{
Czechoslovakia in face of the dictates of Western powers in 1938 in the light of Jan Masaryk's correspondence from London
}

Outline of content: The year 1938 was a turning point in matters of security for both Czechoslovakia and Europe as a whole. The post-Versailles order was collapsing. Germany made its first step towards war with the tacit consent of the former Entente states. Jan Masaryk, who was in London at that time, analysed the behaviour of the British Cabinet and reported it to Prague. His most important task was to sound out London's position regarding Czechoslovakia's direct confrontation with the Third Reich, which skilfully exploited the issue of the Sudeten Germans.

Keywords: interwar Czechoslovakia, partition of Czechoslovakia 1938, Germans in Czechoslovakia, British-Czechoslovak relations, Jan Masaryk

The collapse of the Czechoslovak state in 1938 posed a serious threat to the European order established by the victorious Entente countries at the Versailles Peace Conference in early 1919. The primary losers were the Germans, charged with the responsibility for the outbreak of the Great War. The conference led to the establishment of several new countries, one of which was Czechoslovakia, inhabited not only by Czechs and Slovaks, but also Germans, second in terms of population size. The Western powers have therefore brought into existence a country with ill-advised borders, likely to fall victim, sooner or later, to the expansionist policies of neighbouring Germany. The architects of the post-Versailles order forgot to take this into consideration, carelessly cutting off the local German population from its core. The interwar Czechoslovak state was ruled by the so-called "Hrad group", headed by President Tomáš Garrigue Masaryk. In December 1935, Edvard Beneš became the new president, thus resigning from the post of Czechoslovak Foreign Minister. Earlier, in 1925, owing to a recommendation from his father, Tomás Masaryk's son, Jan, was appointed Czechoslovak envoy in London. Jan Masaryk therefore occupied a prominent position in Czechoslovak diplomacy. 
Meanwhile, since 1937, the country was increasingly threatened by Nazi Germany. In a telegram from London dated 5 November 1937, Jan Masaryk reported that the Nazi party, as well as the German military circles, were considering military action against Czechoslovakia. Masaryk maintained that its proponents would need to initiate an "atmosphere of revolution that would enable active opposition to the policies of the government in Prague". The German power milieus, on their part, believed that "a conflict with Czechoslovakia would someday become inevitable". On 2 December 1937 Masaryk was granted an audience with the French Prime Minister, Camille Chautemps, and his Foreign Minister, Yvon Delbos. Both politicians assured their interlocutor that "Czechoslovakia had nothing to fear and that no "free hand" would be allowed to disrupt Central Europe". Masaryk was also assured that "there has been no changes in the British policies regarding Central Europe and Czechoslovakia". The authorities in London were of the opinion that they could not make specific commitments in advance due to internal political reasons, but the integrity of Czechoslovakia was nonetheless recognised as a prerequisite for Central Europe. ${ }^{1}$

On 6 December 1937, in his conversation with Masaryk, British Foreign Minister Anthony Eden argued that an attack on Czechoslovakia or Austria was out of the question. Hitler had declared that "he has no intention of interfering in the internal affairs of Prague". The degree of hypocrisy that Hitler's words concealed would soon prove Europewide how little he could be trusted. Another question remaining was that of the Franco-Soviet Treaty of Mutual Assistance of 1935. The British authorities confirmed that they had no objections to the FrancoSoviet alliance, but concurrently asserted their belief that Russia lacked the power to act as defender of Czechoslovakia against Germany's expansion, considering the "recent deterioration in Russia's internal situation". Eden was referring here to the escalation of Stalinist terror on an unprecedented scale against all social strata of the Soviet Union. However, it turned out that Stalin's repression was not weakening the country; quite the opposite, in fact. The Soviet Union was becoming stronger and ready to actively participate in international rivalries - at the expense, of course, of the weaker countries of Central and Eastern Europe. ${ }^{2}$

In a telegram dated 24 February 1938, Masaryk reported to the headquarters: "I have spoken with several members of the cabinet, who assured me that our concerns were unfounded, no anti-Czechoslovak scheme was taking place and that the consequences of an attack on Czechoslovakia would differ greatly from those of the violation of the sovereignty of Austria". "Some opposition circles [in Great Britain] expressed compelling assurances of friendship and their will to help", informed Masaryk. "Unfortunately, such promises coming from the opposition are of no use, so I must seek support before the conservatives". "It is a good

\footnotetext{
${ }^{1}$ J. Masaryk, Depeše z Londýna 1938, k vydání připravila Věra Olivová, Prague, 1996, pp. 38-42.

2 Ibid., pp. 43-44.
} 
thing", he continued, "that General Ludvík Krejčí, Chief of the General Staff, has given such a straightforward speech". "We have to bare our teeth a little", advised Masaryk. "The British must understand that our patience is not infinite and that we shall defend ourselves against any aggression". "I also hope", he stressed, "that the president of the republic would provide some official declaration at short notice". He then explained: "A word at the right time from dr. Beneš, the president of the last state east of the Rhine that proudly professes democracy, would be of great support for our cause". Masaryk expressed his conviction that time had come "to increase the Czechoslovak propaganda activities in Great Britain". "I am confident about the final outcome of our efforts, as long as we'll remain strict in our policies in defence of democracy, and will be ready to make sacrifices in its cause", he wrote. "The moment is extremely serious", stressed Masaryk, "and we must put aside all our domestic rivalries" ${ }^{3}$

The envoy was therefore calling for the consolidation of Czechoslovak political forces in order to be able to face the threat of German expansionism. However, he made the error of assuming Czechoslovakia could count on the solidarity of Western powers on the account of their democratic systems, comparable to that existing in his own country. These incorrect calculations regarding actual available support from similar governments soon became apparent, filling the Czechoslovak elites with disappointment. On 24 February 1938, Masaryk informed the headquarters that the current official position of the British government was basically "a non-binding expression of their enduring friendly feelings towards the Czechoslovak nation"; a fictional one, by the way, as these were in fact two separate nations: the Czechs and the Slovaks. Moreover, Masaryk stated that "England's only obligations towards Czechoslovakia were the general ones stemming from the Covenant of the League of Nations". The envoy also claimed that "England was fully aware of the obligations that connected Czechoslovakia with other powers", and reminded that Czechoslovakia had an agreement for mutual assistance with France, which required the latter to assist the former in case of an unprovoked attack. "The English claim to be aware of this", insisted Masaryk. Given this existing balance of forces, the mission in London was left with an extremely difficult task of obtaining assurance from Great Britain that it "would not abandon Czechoslovakia, should France oppose the German invasion on its territory".

In his telegram dated 1 March 1938, Masaryk stated: "I would suggest advising our press not to urge England regarding the adoption of a clear stance on the issue of a guarantee for Czechoslovakia, so that it does not become a subject of political battles between the local government and the Labourite opposition". On 4 March 1938, Masaryk was received by the new Foreign Secretary Edward Halifax, who welcomed the Czechoslovak envoy warmly, as if they were old friends. The British

\footnotetext{
3 Ibid., pp. 45-48.

${ }^{4}$ Ibid., pp. 48-52.
} 
politician brought up a statement by former Foreign Secretary Anthony Eden, who believed that the more Czechoslovakia would accommodate the demands of its Germans, the stronger its international position would be. Masaryk expressed his disapproval of this theory, calling it "the same old song". Halifax reacted by stressing the unfavourable geographical position of Czechoslovakia. Masaryk, however, insisted that the situation required convincing the West of the "importance of Czechoslovakia as the last bastion of democracy". The Czechoslovak envoy expressed the belief that war can be avoided "if we remain unanimous, and through our unity, we convince the Western democracies of our loyalty in case the worst was meant to happen". 5

On 13 March 1938, the German Foreign Minister Joachim von Ribbentrop repeatedly assured his British counterpart Halifax that Germany did not have any aggressive intentions against Czechoslovakia. When informed of these pronouncements, Masaryk cautioned Halifax that he could not trust these words and expressed his conviction that Germany would still act however they please. Halifax also shared this point of view; however, he believed that the Germans had no interest in carrying out an assault on Czechoslovakia in the near future. Their involvement in the Anschluss seemed to defer the possibility of such an attack to some later date. Halifax tried to enquire of Masaryk about the veracity of Göring's assurances that Germany would not take any steps against Czechoslovakia. Masaryk replied that this statement could be true for the moment, as "Germany would require some time to digest Austria first". Impressed by Masaryk's answer, Halifax expressed his wish to support the Czechoslovak side. He confessed, however, that he did not know how to proceed further in this regard. Masaryk suggested that Göring's words should be treated as Germany's official position. When asked by Halifax what would happen if Germany provoked unrest in Czechoslovakia, to then invade the country, Masaryk replied: we would shoot. ${ }^{6}$

On 18 March 1938, Masaryk experienced an unpleasant conversation with Orme Sargent, Halifax's secretary. Sargent asserted that, due to public opinion, the British government could not explicitly support Czechoslovakia as long as the authorities in Prague would not make any concessions to the Sudeten Germans, so that their complaints - which he considered legitimate - could be resolved positively. Masaryk advised his superiors to urge the Czechoslovak government "to present constructive solutions to the issue of our Germans". The envoy cautioned that the idea of a plebiscite would be extremely dangerous, as Hitler had recently used this exact method to invade Austria. Masaryk pointed out that the English public opinion seemed to be taking Czechoslovakia's side, "but they do not believe that we are doing everything in our power for our Germans". Characteristic of the British attitude was the position of War Secretary Leslie Hore-Belisha, who

\footnotetext{
${ }^{5}$ Ibid., pp. 53-55.

${ }^{6}$ Ibid., pp. 58-60.
} 
openly told American reporters on 28 April 1938 that the fate of Czechoslovakia was sealed and that nothing would protect it against German rule, achievable even without direct invasion. The British politician believed that even before the democratic states will decide to confront Germany, "the minorities in Czechoslovakia and elsewhere will already have been incorporated into the Reich". During Masaryk's meeting, on 5 April 1938, with the British Under-Secretary of State Alexander Cadogan, the latter admitted that, should the Czechoslovak side would occasionally require help from the British, he could not offer any obliging promises; but he insisted nonetheless, on Halifax's behalf, that they would do anything possible within Great Britain's capacity. ${ }^{7}$

Cadogan also expressed "great mistrust toward Russia and doubts whether the Russian authorities could effectively intervene beyond their borders". "That does not mean, however", Cadogan continued, "that one should not cooperate politically with Russia; on the contrary, making the Germans face the threat of Russia's interference is in Czechoslovakia's interest, as in spite of all their proclamations, the Germans are deeply afraid of Russia". The leader of the Sudeten German Party, Konrad Henlein, demanded autonomy for Czechoslovakia's territories inhabited by the German population. In a telegram dated 14 May 1938, Masaryk indulged in the following reflection: "We have led the Germans by the nose for eighteen years of unfulfilled promises", thus causing "a radicalisation within the Sudeten German Party, which by and large supports the Anschluss". "I have a definite feeling", telegraphed Masaryk on 14 May 1938, "that Henlein would not at all be pleased by the annexation of Czechoslovak lands by the German Reich". As for the Czechoslovak-Soviet agreement, Henlein considered it a threat to peace in Europe, even though he still recognised the importance of the USSR in the international scene.

Halifax indicated that the British government was disappointed with the weak progress of the talks conducted by the Czechoslovak authorities and repeatedly called for more decisive negotiations and far-reaching concessions to the German population. Masaryk tried to justify the circumstances with the fact that the local public opinion was not accustomed to the idea of large concessions. Halifax warned that the attitude of the Czechoslovak authorities raised serious discontent among Western powers. ${ }^{8}$

On 29 June 1938, at a meeting of the British Cabinet, Chamberlain openly accused President Beneš and the Czechoslovak government of delaying the negotiations regarding the settlement of the issue of the Sudeten Germans on purpose. Suspicions were raised that the authorities in Prague actively avoided reaching an eventual consensus with the Sudeten Germans and did not treat them as equals. It was also said that Russia was pushing Czechoslovakia into provoking a war, and

\footnotetext{
7 Ibid., pp. 61-72.

8 Ibid., pp. 76-81.
} 
that Beneš concurred. Masaryk referred to the authors of such claims as "propagandists". On 26 August 1938, Halifax asked the French chargé d'affaires in London Roger Cambon about France's position regarding the whole situation and how they would react if Hitler were to invade Czechoslovakia. Cambon replied that France has envisioned all the possible worst scenarios, without excluding the possibility of some surprise. In the event of an attack on Czechoslovakia, several days would pass before the French public opinion would make its mind. Ultimately, France's commitments stemming from its alliances would have a decisive impact. Halifax agreed that the situation was extremely serious. He was aware that no warnings could stop Hitler, should he chose to attack Czechoslovakia. Cambon also reminded that in France, the entire left advocated supporting the Czechoslovak Republic. $\mathrm{He}$ also pointed out that a large part of the right, having its selfish, mainly financial interests in mind, desired peace at any price. ${ }^{9}$

Meanwhile, in Czechoslovakia, rumours were being spread suggesting that a rebellion against Beneš was being set up. Masaryk pointed out that it would thus be advisable to pay attention to the loyalty of the army and its preparedness for defensive action, as well as the unity of the Czechoslovak society. The envoy also cautioned against attempts at destabilisation by agents provocateurs. A secret informant reported on 14 September 1938 to Masaryk that Chamberlain was not convinced whether France and the Soviet Union would rush to help Czechoslovakia. Chamberlain did not rule out the possibility of Hitler invading Czechoslovakia and occupying German-inhabited territories, to then declare a truce and perpetual peace. In his conversation with the British envoy in Paris, Eric Phipps, on 14 September 1938, the French Foreign Minister Georges Bonnet stated that peace should be kept even at the price of Czechoslovakia's fall, as France was not prepared for war and refuses to fight for another country. Masaryk's informant advised the Czechoslovak side to begin preparations for the imminent conflict, as it was the only scenario where they count on support from France and Great Britain. The Egyptian ambassador, freshly back from Berlin, had heard from the German Foreign Minister Ribbentrop that Hitler was determined to settle the Sudeten issue and nothing in the world would be able to dissuade him. If things could be fixed by peaceful means, that would be fine; but otherwise, war was inevitable. Ribbentrop stated that Great Britain ought not interfere, and that Germany would handle the problem on its own. In a note to Beneš from 14 September 1938, Masaryk stated that the Czechoslovak authorities could not trust any of Hitler's guarantees. ${ }^{10}$

On 20 September 1938, Masaryk informed the headquarters that Great Britain and France proposed far-reaching changes to the borders of the Czechoslovak state. The proposal was presented as a fait accompli, even though the day before

\footnotetext{
9 Ibid., pp. 85-89.

${ }^{10}$ Ibid., pp. 96-97.
} 
the Czechoslovak authorities had requested prior consultations. Masaryk did not hesitate to call the behaviour of the Western powers a unique kind of "savagery". He also believed that if the adoption of the proposals of the Western powers were to be negotiated, guarantees should be sought from all European powers, including the Soviet Union, but excluding the neighbouring countries. Masaryk was informed that the French General Staff considered itself completely unprepared for warfare, especially in the field of aviation, and that an intracontinental conflict would be a tragedy. "I can barely believe it", he commented. Masaryk then learned from Halifax, on 25 September 1938, that the British Prime Minister Neville Chamberlain was still convinced that Hitler was trustworthy (acting bona fide), and that as soon as he would obtain the Sudeten, he would grant peace to Europe once and for all. The British assessment of the situation left Masaryk astounded. He called it criminal naivety. Halifax admitted that Chamberlain was playing the role of an emissary between the British Prime Minister and the Chancellor of the Reich. ${ }^{11}$

The issue of the territories inhabited by the so-called Sudeten Germans became the direct cause of Czechoslovakia's defeat in 1938. The Germans had the right to demand the creation of their own state in accordance with the principle of self-determination of nations. In 1921, the German minority accounted for $23.4 \%$ of the population and were the second largest ethnic group in the country. When defining the national borders, the victorious Entente powers could have prevented this unnecessary conflict, due to which Europe suddenly found itself in 1938 on the threshold of another world war. However, they failed to do so, lacking political imagination; and Czechoslovakia has paid the price.

\section{Czechoslovakia in face of the dictates of Western powers in 1938 in the light of Jan Masaryk's correspondence from London}

\section{Abstract}

The issue of the lands inhabited by the Sudeten Germans within the Czechoslovak state became the reason for the fall of Czechoslovakia in 1938. The German minority had the right to demand the creation of an independent state under the principle of self-determination. In 1921, there was a substantial German minority of 23.4 percent in Czechoslovakia, making it the second largest nationality in the republic. When defining the new borders, the victorious Entente powers could have prevented an unnecessary conflict, due to which Europe suddenly found itself in 1938 on the threshold of another world war. However, they failed to do so, lacking political imagination; and Czechoslovakia has paid the price.

11 Ibid., pp. 98-102. 
Marek Kazimierz Kamiński, Prof. Dr. hab., works at the Institute of History of the Polish Academy of Sciences; specialises in the $20^{\text {th }}$-century history of Poland, universal history and the history of international relations; author of numerous publications on Polish-Czechoslovak relations and issues; the former editor-in-chief of the periodical Studia z Dziejów Rosji i Europy Srodkowo-Wschodniej (Studies in the History of Russia and Central-Eastern Europe). 